\title{
Pengaturan Restrukturisasi Kredit Dalam Penyelamatan Usaha Mikro, Kecil Dan Menengah Di Era Pandemi Covid-19
}

\author{
Robiatul Adawiyah'1, Rumawi ${ }^{2}$ \\ ${ }^{1}$ Fakultas SyariahIAIN Jember, E-mail: robiatuladawyh27@gmail.com \\ ${ }^{2}$ Fakultas Syariah IAIN Jember, E-mail: rumawi@iain-jember.ac.id
}

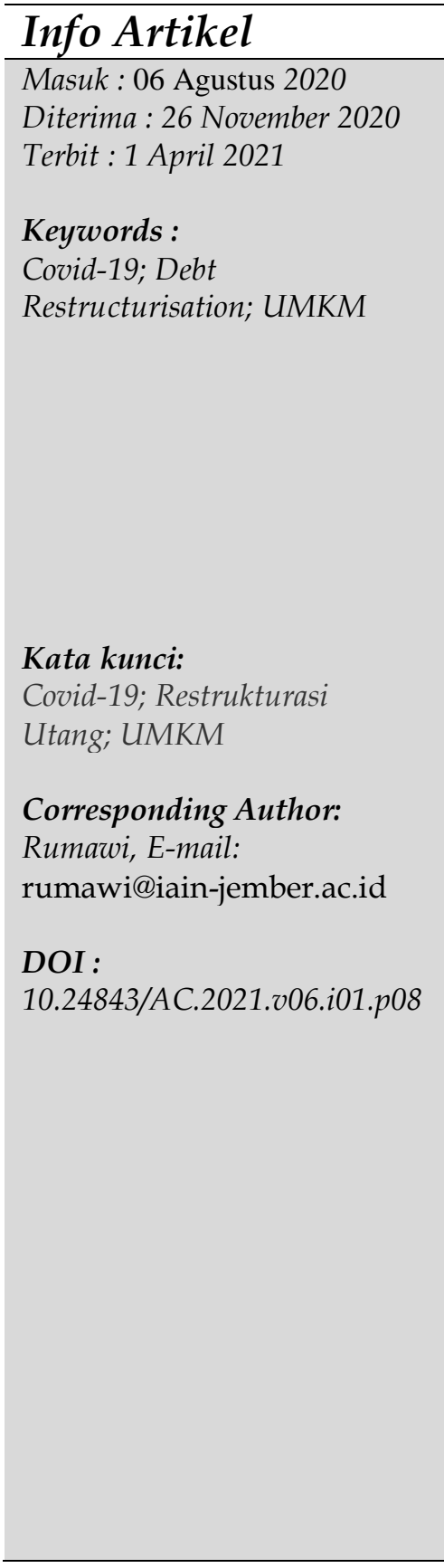

\begin{abstract}
The purpose in this article is to determine the credit restructuring regulation in Indonesian law, how force majeure nisbi in Covid-19 pandemic, and how credit restructuring policy in regulation to replace law number 1 year 2020 to UMKM at Covid-19 pandemic. This research is based on a normative-law research methodology. This article concludes that the regulations that have been used in credit restructuring during the covid-19 pandemic is constitution number 37 year 2004 and regulation to replace law number 1 year 2020. Situation was force majeure nisbi, which was the release of the issuance of liabilities until the situation or conditions improved. The restructurisation of debt can help Covid-19 societ to be affected by its inability to complete its debt and support the economic world to survive the crisis of Covid-19.
\end{abstract}

\begin{tabular}{l} 
Abstrak \\
\hline Tujuan dalam artikel ini adalah untuk mengetahui bagaimana \\
pengaturan restrukturisasi kredit di dalam hukum Indonesia, \\
bagaimana force majeure nisbi dalam pandemi Covid-19 dan \\
bagaimana kebijakan restrukturisasi kredit dalam Perpu Nomor 1 \\
Tahun 2020 bagi UMKM di era pandemi Covid-19. Penelitian \\
ini didasarkan pada metodologi penelitian hukum normatif. \\
Artikel ini menyimpulkan bahwa regulasi yang telah digunakan \\
dalam restrukturisasi kredit di era Covid-19 adalah UU No.37 \\
Tahun 2004 dan Perpu Nomor 1 Tahun 2020 . Situasi pandemi \\
Covid-19 merupakan force majeure nisbi yakni pembebasan \\
pemenuhan kewajiban bersifat penundaan kewajiban bagi debitur \\
sampai situasi atau kondisi membaik. Restrukturisasi kredit \\
dengan dikeluarkannya Perpu Nomor 1 Tahun 2020 dapat \\
membantu masyarakat terdampak Covid-19 sehingga tidak bisa \\
menuntaskan kewajibannya untuk membayar utang serta \\
menyokong dunia ekonomi sehingga dapat bertahan di tengah \\
krisis Covid-19.
\end{tabular}




\section{Pendahuluan}

Pada Desember tahun 2019 muncul corona virus disease 19 (Covid-19) yang menggegerkan dunia. Virus ini berasal dari Wuhan, China lalu menyebar dengan penularan melalui kontak langsung antar manusia ke berbagai negara termasuk Indonesia1. Di hitung per 3 Agustus 2020, sekitar 113.134 masyarakat Indonesia positif tertular Covid-19. ${ }^{2}$ Covid-19 meluluhlantakan seluruh aspek, terutama aspek ekonomi dan usaha. Di dalam UMKM mengalami krisis, lalu industri keuangan sebagai sumber pendanaan bagi pelaku usaha seperti perusahaan pembiayaan dan perbankan terkena efek dominonya. ${ }^{3}$

Laporan dari kementrian koperasi dan Usaha, Mikro, Kecil dan Menengah (UMKM) bahwa 49\% pelaku usaha dapat mengalami gulung tikar. Selain itu, laporan dari menteri tenaga kerja bahwa $90 \%$ pekerja dirumahkan dan $10 \%$ terkena Pemutusan Hubungan Kerja (PHK). Jumlah pekerja yang dirumahkan adalah sekitar 1,5 juta pekerja. Pekerja tersebut meliputi 1,24 juta sebagai karyawan formal dan 265 ribu karyawan non formal. ${ }^{4}$ Pelaku usaha kini sedang mengalami beban ekonomi yang besar sedangkan di satu sisi pemasukan mengalami penurunan. Hal ini disinyalir menyebabkan angka gagal bayar melonjak sehingga perlu adanya jalan keluar.

Sejak 31 Maret 2020, secara sah pemerintah mengeluarkan Perppu Nomor 1 Tahun 2020 tentang kebijakan Keuangan Negara dan Stabilitas Sistem Keuangan Untuk Penanganan Pandemi Covid-19.5 Perpu dimaksud absah jadi Undang-Undang Nomor 2 Tahun 2020 setelah disetujui oleh Dewan Perwakilan Rakyat (DPR) pada 18 Mei 2020.6 Restrukturisasi utang bagi pelaku usaha sebagai debitur menjadi salah satu cara untuk mengantisipasi tingginya kredit macet (non-performing loan). Dikeluarkannya Perpu Nomor 1 Tahun 2020 disambut baik oleh Otoritas Jasa Keuangan, Bank

\footnotetext{
1 Yuliana, Y. (2020). Corona Virus Disease (Covid-19): Sebuah Tinjauan Literatur. Wellnes and Healthy Magazine, 2(1), p. 187

2 Indonesia, C. (2020). Update Corona 3 Agustus : 113.134 Positif, 70.273 Sembuh. CNN Indonesia. https://m.cnnindonesia.com/nasional/20200803144603-20-531637/update-corona3-agustus-113134-positif-70237-sembuh/

${ }^{3}$ Rizki, M. J. (2020). Praktisi Hukum dan Bankir Harapan Restrukturasi Utang Jadi "Obat" Covid-19.Www.hukumonline.com.

https://www.hukumonline.com/berita/baca/lt5f06e66c6cebc/praktisi-hukum-dan-bankirharapkan-restrukturisasi-utang-jadi-obat-covid-19/

${ }^{4}$ Hanoatubun, S. (2020). Dampak Covid-19 terhadap Prekonomian Indonesia. EduPsyCouns: Journal of Education, Psychology and Counseling, 2(1), 146-153. https://ummaspul.ejournal.id/Edupsycouns/article/view/423, p. 151

${ }^{5}$ OJK. (2020b). Siaran Pers: OJK Mendukung dan Menindaklanjuti PERPU 1 Tahun 2020. Siaran Pers. https://www.ojk.go.id/id/berita-dan-kegiatan/siaran-pers/Pages/Siaran-Pers-OJKMendukung-dan-Menindaklanjuti-PERPU-1-Tahun-2020.aspx

${ }^{6}$ Juliani, H. (2020). Analisis Yuridis Kebijakan Keuangan Negara dalam Penanganan Pandemi Covid-19 Melalui Peraturan Pemerintah Pengganti Undang-Undang Nomor 1 Tahun 2020. Administrative Law $\& \quad$ Governance Journal, 3(2), 329-348. https://ejournal2.undip.ac.id/index.php/alj/article/view/8043, p. 374
} 
Indonesia, dan Lembaga Penjamin Simpanan karena memudahkan program restrukturisasi. ${ }^{7}$

Perpu Nomor 1 tahun 2020 ditetapkan sebagai instrumen yuridis dalam penanganan Covid-19 setelah banyak ditemukan kelumpuhan dari berbagai aspek yang disebabkan oleh Covid-19. Perpu Nomor 1 tahun 2020 merupakan diskresi konstitusional. ${ }^{8}$ Diskresi konstitusional sebagai hak presiden dan pejabat pemerintahan yang berdasar pada Pasal 22 ayat (1) UUD 1945: "Dalam hal ikhwal kegentingan yang memaksa, Presiden berhak menetapkan peraturan sebagai pengganti undang-undang." 9 Hal tersebut lalu disebutkan parameternya dalam Putusan MK Nomor 138/PUU-VII/2009 ayat (1) "karena kebutuhan yang mendesak untuk menyelesaikan masalah hukum secara cepat berdasarkan Undang-Undang." 10

Pada tahun 2000, restrukturisasi utang menjadi salah satu upaya dari pemerintah untuk menyelamatkan perekonomian paska krisis ekonomi global. Setelah itu, mulai tahun 2004 pemerintah mengesahkan UU Nomor 37 Tahun 2004 tentang Kepailitan dan Penundaan Kewajiban Pembayaran Utang selanjutnya disebut UU PKPU yang dapat dimanfaatkan pelaku usaha untuk merestrukturisasi utang melalui jalur pengadilan.11 Restrukturisasi utang terus meningkat sejak tahun 2012 dan juga dilakukan oleh beberapa negara selain Indonesia seperti Jepang, Kenya, India, Malaysia dan beberapa negara lain. ${ }^{12}$ Saat ini Indonesia kembali mengalami krisis ekonomi karena pandemi Covid-19. Meskipun sama-sama menghadapi krisis ekonomi, terdapat perbedaan antara keduanya, yakni krisis ekonomi pada tahun 1998 merupakan krisis perbankan sehingga dapat di prediksi sedangkan krisis ekonomi di masa pandemi Covid-19 merupakan gejala non-alam sehingaa tidak dapat diprediksi. ${ }^{13}$

Dengan adanya pandemi Covid-19 restrukturisasi kembali digemakan oleh pemerintah sebagai upaya membantu pelaku usaha yang terancam gulung tikar khususnya UMKM. Situasi pandemi Covid-19 merupakan force majeure nisbi yang memiliki makna bahwa ada pembebasan pemenuhan kewajiban bersifat penundaan kewajiban bagi debitur sampai situasi atau kondisi membaik. ${ }^{14}$

\footnotetext{
7 Peraturan Pemerintah Pengganti Undang-Undang Nomor 1 Tahun 2020 Tentang Kebijakan Keuangan Negara dan Stabilitas Sistem Keuangan untuk Penanganan Pandemi Corona Virus Disease 2019 (COVID-19) dan/atau dalam Rangka Menghadapi Ancaman yang Membahayakan Perekonomian Nasional dan/atau Stabilitas Sistem Keuangan.

8 Juliani, H., Op. Cit, p. 329

9 Undang-Undang Dasar Negara Republik Indonesia Tahun 1945, (1945).

10 Indonesia, M. K. R. (n.d.). Putusan Mahkamah Konstitusi Republik Indonesia Nomor 138/PUUVII/2009.

11 Hariyadi, H. (2020). Restrukturasi Utang Sebagai Upaya Pencegahan Kepailitan Pada Perseroan Terbatas. SIGn Jurnal Hukum, 1(2), p. 120

${ }^{12}$ Rizki, M. J., Op. Cit.

${ }^{13}$ Kaya, P. B. T. A. \&, \& Dharmawan, N. K. S. (2020). Kajian Force Majeure Terkait Pemenuhan Prestasi Perjanjian Komersial Pasca Penetapan Covid-19 Sebagai Bencana Nasional. Kertha Semaya : Journal Ilmu Hukum; Vol 8 No 6 (2020), 8(6), 891-901. https://ojs.unud.ac.id/index.php/kerthasemaya/article/view/60631, p. 892

14 Soemadipradja, R. S. S. (2010). Penjelasan Hukum tentang Keadaan Memaksa. Nasional Legal Reform Program, p. 12
} 
Data menunjukkan bahwa pada akhir Juni 2020 sebanyak 6.557 .903 debitor atau Rp 741 triliun direstrukturisasi oleh perbankan. Selanjutnya, sejumlah 3.740 .837 debitor atau Rp 134 triliun direstrukturisasi oleh perusahaan pembiayaan. ${ }^{15}$ Dalam Perppu Nomor 1 Tahun 2020 untuk mendapatkan restrukturisasi utang debitur harus memenuhi beberapa persyaratan yaitu beritikad baik dan terdampak pandemi Covid-19. Melalui program restrukturasi ini diharapkan pelaku usaha terdampak Covid-19 dapat terbantu khususnya UMKM sehingga dapat bangkit dan memiliki kesempatan untuk melunasi utang.

Penelitian yang membahas tentang pengaturan restrukturisasi kredit dalam penyelamatan usaha mikro, kecil dan menengah di era pandemi Covid-19 sudah pernah dilakukan oleh para peneliti sebelumnya. Hal ini sesuai dengan penelusuran yang dilakukan dengan cara melihat dari beberapa literatur yang ada, maka setidaknya ditemukan dua literatur yang erat kaitannya dengan permasalahan yang ada dalam penelitian ini, yaitu: pertama, Lili Marlinah (Universitas Bina Sarana Informatika, Jakarta) dengan judul "Peluang dan Tantangan UMKM Dalam Upaya Memperkuat Perekonomian Nasional Tahun 2020 Ditengah Pandemi Covid 19,"16 dan kedua, Ashinta Sekar Bidari (Universitas Surakarta), Frans Simangunsong (Universitas 17 Agustus 1945 Surabaya), dan, Karmina Siska (Universitas Surakarta) dengan judul "Sektor Perbankan Di Covid-19,"17 keduanya pada tahun 2020. Dalam penelitian tersebut, Lili Marlinah membahas tentang pandemi COVID-19 membawa dampak signifikan bagi seluruh sisi kehidupan masyarakat, terlebih lagi bagi para pelaku usaha koperasi, usaha mikro, Kecil, dan menengah yang perputaran ekonominya sangat bergantung pada runitinitas lalu lintas barang, jasa, dan manusia, yang saat ini sedang mengalami masa keterbatasan pergerakan (PSBB); sedangkan Ashinta Sekar Bidari, Frans Simangunsong, dan, Karmina Siska tentang relaksasi kredit berupa peningkatan kualitas kolebilitas kredit dan restrurturisasi kredit bagi debitur yang terdampak. Melihat keadaan masyarakat sekarang ini tengah mengalami krisis ekonomi, terutama masyarakat UMKM maka OJK memberikan stimulus kepada debitur yang terdampak penyebaran Covid-19 dalam sistem perbankan.

Dalam penelitian ini diuraikan mengenai analisa terhadap: pertama, dasar pengaturan restrukturisasi utang dalam hukum Indonesia; kedua, situasi pandemi Covid-19 merupakan force majeure; dan ketiga, ketepatan kebijakan restrukturisasi utang dalam Perpu Nomor 1 Tahun 2020 bagi UMKM di era pandemi Covid-19. Berdasarkan isu hukum dalam penelitian ini dan telah dilakukan perbandingan dengan melakukan penelitian terdahulu, sehingga penelitian mempunyai perbedaan dengan dua penelitian sebelumnya. Hal-hal yang membedakan diantaranya bisa dilihat bahwa dalam penelitian terdahulu membahas tentang tantangan bagi UMKM di tahun 2020 dalam wabah Covid 19 dan kinerja perbankan atas kebijakan pemerintah dalam menangani Covid-19; sedangkan penelitian ini membahas tentang dasar pengaturan restrukturisasi utang dalam hukum Indonesia;

15 Sidik, S. (2020). OJK: Restrukturasi Nasabah Leasing Sudah Tembus Rp. 134 T. Cnbcindonesia. https://www.cnbcindonesia.com/market/20200708120817-17-171108/ojkrestrukturasi-nasabah-leasing-sudah-tembus-rp-134-t

16 Marlinah, L. (2020). Peluang dan Tantangan UMKM Dalam Upaya Memperkuat Perekonomian Nasional Tahun 2020 Ditengah Pandemi Covid 19. Jurnal Ekonomi, 22(2), p. 123

${ }^{17}$ Bidari, A. S., Simangunsong, F., \& Siska, K. (2020). SEKTOR PERBANKAN di COVID-19. Jurnal Pro Hukum, 9(1), p. 8 
kedua, situasi pandemi Covid-19 merupakan force majeure nisbi; dan ketiga, ketepatan kebijakan restrukturisasi utang dalam Perpu Nomor 1 Tahun 2020 bagi UMKM di era pandemi Covid-19.

Berdasarkan uraian yang tertuang dalam latar belakang diatas yang menjadi permasalahan dalam penelitian ini dapat dirumuskan sebagai berikut: pertama, apakah dasar pengaturan restrukturisasi utang dalam hukum Indonesia? kedua, Apakah situasi pandemi Covid-19 merupakan force majeure? dan ketiga, Apakah kebijakan restrukturisasi utang dalam Perpu Nomor 1 Tahun 2020 bagi UMKM di era pandemi Covid-19 sudah tepat? Penelitian ini bertujuan untuk menganalisis: pertama, dasar pengaturan restrukturisasi utang dalam hukum Indonesia; kedua, situasi pandemi Covid-19 merupakan force majeure nisbi; dan ketiga, ketepatan kebijakan restrukturisasi utang dalam Perpu Nomor 1 Tahun 2020 bagi UMKM di era pandemi Covid-19.

\section{Metode Penelitian}

Penulisan ini dengan metode riset yuridis normatif (legal research). ${ }^{18}$ Pendekatan yuridis normatif atau penelitian doktrinal adalah penelitian hukum dengan melihat tujuan hukum, nilai keadilan, validitas aturan hukum, konsep hukum dan norma hukum serta memberikan prekripsi apa yang seyogyanya ${ }^{19}$ Penelitian ini menggunakan pendekatan perundang-undangan (statue approach), dengan pendekatan ini penulis menggunakan legislasi dan regulasi yang dilakukan dengan mengkaji suatu Yakni Undang-Undang Nomor 37 Tahun 2004, Peraturan Pemerintah Pengganti Undang-Undang Nomor 1 Tahun 2020 Dan UU Nomor 2 Tahun 2020. Sumber bahan hukum penelitian ini adalah perpaduan dari bahan-bahan sekunder berupa artikel maupun jurnal dalam media internet. ${ }^{20}$ Lalu sumber bahan hokum primer digunakan untuk memperjelas bahan sekunder berupa pendapat ahli dan buku-buku yang membahas restrukturisasi. Pengumpulan bahan hukum antara lain studi peraturan perundang-undangan dan kepustakaan. Kemudian, materi norma dikaji dan dianalisis dengan cara pandang yang dipakaikan untuk menanggapi pokok-pokok problematika riset. ${ }^{21}$ Kesimpulan dibuat atas analisis pokok masalah.

\section{Hasil Dan Pembahasan}

\subsection{Pengaturan Restrukturisasi Utang di dalam Hukum Indonesia}

UU PKPU dibuat dalam rangka untukmelindungi kepentingan kreditur.Kepentingan kreditur tersebut seperti upaya mendapatkan pelunasan terhadap piutang sesuai dengan prinsip hukum adil, cepat, terbuka dan efektif bagi kreditur. ${ }^{22}$ Selain itu, juga sebagai regulasi yang melindungi debitur untuk melunasi utangnya dan sebagai payung hukum guna membantu debitor kesulitan menuntaskan kewajiban membayar utang.

\footnotetext{
${ }^{18}$ Ibrahim, J. (2008). Teori Metodologi Penelitian Hukum Normatif. Bayumedia Publishing, p. 295

${ }^{19}$ Marzuki, P. M. (2016). Penelitian Hukum. Kencana Prenadamedia Group, p. 44

20 Ibid., p. 181

${ }^{21}$ Ibid., p. 237

${ }^{22}$ Undang-Undang Nomor 37 Tahun 2004 Tentang Kepailitan Dan Penundaan Kewajiban Pembayaran Utang, (2004).
} 
Dalam Pasal 144 UU PKPU perlindungan oleh hukum guna memberi kesempatan bagi debitur untuk lepas dari utang terutama bagi debitur yang beritikad baik ditandai dengan teratur membayar cicilan yang telah ditetapkan. ${ }^{23}$ Adanya pandemi Covid-19 menjadikan UU PKPU menjadiregulasi yang ikut andil membantu masyarakat yang memiliki permasalahan gagal bayar dengan program restrukturisasi. ${ }^{24}$

Program restrukturisasi utang digemakan oleh pemerintah untuk membantu pelaku UMKM di masa pandemi Covid-19. Perlu diketahui makna dari PKPU sebelum mengetahui lebih lanjut mengenai restrukturisasi utang. Definisi dari PKPU atau Suspension of payment adalah masa ketika kreditor serta debitor diberi waktu guna bermusyawarah mengenai cara pelunasan utang dan restrukturisasi utang atas perjanjian yang telah dibuat oleh undang-undang di pengadilan niaga melalui putusan hakim. Dalam arti lain PKPU adalah kesempatan untuk debitur melaksanakan kewajiban membayar utang dan mendapat jaminan bahwa debitur tidak dapat dinyatakan permohonan pailit. ${ }^{25}$

PKPU dibagi menjadi dua bagian yakni PKPU Sementara dan PKPU Tetap. Prosedur dalam PKPU yakni dimulai dari permohonan, (sini) debitur mengemukakan rencana penyelesaian / perdamaian atau composition plan. Dalam rencana perdamaian salah satunya adalah restrukturisasi utang hingga PKPU berakhir. Dalam PKPU, perdamaian diatur dalam Pasal 265. Perdamaian menjadi elemen yang paling mendasar berupa suatu praktek berisi sebuah kesepakatan yang terkandung dalam perjanjian perdamaian atau disebut dengan putusan homologasi yang disahkan oleh Pengadilan Niaga. Fungsi perdamaian dalam PKPU yaitu penyelesaian pelunasan hutang dan kesepakatan pada restrukturisasi hutang debitor. Adanya perdamaian tersebut membuat adanya restrukturisasi yang akan selalu ditemukan dalam PKPU. ${ }^{26}$

Restrukturisasi utang adalah rencana perdamaian dalam proses kepilitan maupun PKPU dengan melakukan perbaikan struktur modal berkenaan dengan debitur yang mempunyai persoalan untuk memenuhi kewajibannya dalam membayar utang. Pada definisi yang lain restrukturisasi utang juga dapat disebut upaya memperbaiki struktur modal ketika perusahaan sedang dalam kondisi insolvable atau ancaman insolvency. ${ }^{27}$ Meskipun ada penolakan mengenai rencana perdamaian yang diajukan oleh debitur, keduanya, antara PKPU atau Kepailitan sama-sama memiliki kesempatan untuk merencanakan penyelesaian sebagai bagian pada restrukturisasi utang. Maksud dari perubahan ini adalah agar debitur dapat bangkit dengan dasar keuangan yang lebih kuat. ${ }^{28}$

${ }^{23} \mathrm{Ibid}$.

24 Pramudita, S. A., Kartikasari \& Cahyadini, A. (2020). Kedudukan Hukum Menkominfo Dalam Pelaksanaan Perdamaian Menurut Undang-Undang Nomor 37 Tahun 2004 Tentang Kepailitan dan Penundaan Kewajiban Pembayaran Utang. Jurnal Ilmu Hukum Legal Standing, 4(1), p. 103

25 Ibid., p. 109

${ }^{26}$ Ibid., p. 110-111

${ }^{27}$ Respatia, W \& Fidiana, F. (2010). Kebijakan Restrukturasi Utang Melalui Debt to Equity Swap. Ekuitas, 14(1), p. 96

28 Suyatno, R. A. (2012). Pemanfaatan Penundaan Kewajiban Pembayaran Utang: Sebagai Upaya Mencegah Kepailitan. Kencana Prenada Media Group, p. 5 
Pada UU PKPU menerangkan bahwa debitur memiliki kemungkinan untuk memohon penundaan pembayaran hutang melalui pengadilan niaga. ${ }^{29}$ Debitur memohonkan penundaan kewajiban pembayaran hutang (surseance van betaling) secara umum bertujuan agar tidak terjadi kepailitan dengan rencana penyelesaian yang meliputi pembayaran semua atau sebagian hutang kepada kreditur. ${ }^{30}$ Demi menghindari likuidasi kekayaan debitur, penundaan kewajiban pembayaran hutang sebagai cara yang terbaik. ${ }^{31}$

Terdapat dua pihak utama dalam hal ini yaitu kreditur dan debitur. Orang yang dapat menagih di pengadilan karena memiliki piutang dari sebuah undang-undang atau perjanjian disebut kreditur sedangkan orang yang memiliki utang dan pelunasannya dapat dilakukan di muka pengadilan karena sebuah perjanjian atau undang-undang disebut debitur. ${ }^{32}$ Beberapa cara dalam restukturisasi utang adalah sebagai berikut: (a) Hair Cut, yaitu pembebasan hutang bisa terjadi atas semua atau sebagian hutang; (b) Debt Rescheduling, yaitu penjadwalan kembali hutang dengan menambah tanggal jatuh tempo pembayaran kembali hutang dan anakan; (c) Debt to asset swap, yaitu pengalihan asset kepada kreditur untuk penyelesaian hutang; serta (d) Debt to equity swap, yaitu perubahan hutang menjadi penyertaan modal.

Kemudian, berikut beberapa kebijakan restrukturisasi utang yang dilakukan oleh pihak bank, yaitu : 1) Penyusutan bunga, 2) jangka waktu kredit diperpanjang, 3) Penurunan utang bunga kredit, 4) penyusutan utang pokok kredit, 5) penaikan fasilitas kredit, 6) Penyertaan saham sementara. Ada 2 syarat untuk mengajukan restrukturisasi kredit pada bank yakni apabila debitor mengalami kesulitan dalam melaksanakan pembayaran bunga kredit dan jikalau debitor mempunyai prospek usaha bagus dan dinilai mampu melaksanakan kewajiban setelah kredit direstrukturisasi. Dalam menentukan kualifikasi debitor yang memperoleh restrukturisasi hutang, bank harus memperhatikan beberapa kriteria yang didasarkan pada undang-undang. Perhitungan Present Value dan pendakuan kerugian restrukturasi menjadi pengutamaan. Kemudian, dalam melakukan restrukturisasi utang bank harus mempunyai kebijakan dan dasar tertulis yang nantinya akan digunakan sebagai pedoman. ${ }^{33}$ Beberapa proses di atas merupakan proses negosiasi antara debitur dan kreditur. Kedua pihak memilih model restrukturisasi untuk mencapai kesepakatan dengan memahami faktor-faktor keberhasilan restrukturisasi utang. ${ }^{34}$

Selain UU PKPU berikut Beberapa regulasi yang mengatur tentang restrukturisasi hutang di Indonesia, diantaranya: Undang-Undang Nomor 10 Tahun 1998 tentang

\footnotetext{
${ }^{29}$ Hariyadi, H, Op. Cit., p. 120

30 Suyatno, R. A., Op. Cit., p. 5

${ }^{31}$ Sunarmi, R. Harianto, D. \& Azwar, T. K. D. (2016). Konsep Utang dalam Hukum Kepailitan Dikaitkan dengan Pembuktian Sederhana (Studi Putusan No: 04/PDT.SUS.PAILIT/2015/PN.NIAGA.JKT/PST). USU Law Journal, 4(4), p. 35 32 Ibid., p. 103

33 Indonesia, G. (2020). Peraturan Perbankan. GB Indonesia. https://www.bi.go.id/id/peraturan/perbankan/Documents/1cd6b7873ef54732b2981218c54aa aa30pbi7205c1.pdf

${ }^{34}$ Respatia, W \& Fidiana, F., Op. Cit., p. 83
} 
Perubahan Atas Undang-Undang Nomor 7 Tahun 1992, Peraturan Bank Indonesia Nomor: 7/2/PBI/2005, Surat Edaran Bank Indonesia Nomor: 7/3/DPNP, Peraturan Bank Indonesia Nomor: 2/15/PBI/2000 tentang Perubahan Surat Keputusan Direksi Bank Indonesia Nomor: 31/150/Kep/Dir, Surat Edaran Bank Indonesia Nomor 7/190/DPNP/IDPnP dan Surat Edaran Bank Indonesia Nomor: 7/319/DPNP/IDPnP, Peraturan Pemerintah Nomor 14 Tahun 2005 yang diubah dengan Peraturan Pemerintah Nomor 3 Tahun 2006, dan Peraturan Pemerintah Nomor 23 tahun 2020.

Berdasarkan analisis terhadap karakteristik dari undang-undang dan perpu di atas, telah jelas bahwa restrukturisasi merupakan jalan yang tepat untuk diambil sebelum terjadi kebankrutan. Undang-Undang Nomor 37 Tahun 2004 berlaku sejak pemulihan ekonomi Indonesia pasca krisis moneter 1998, sedangkan Perpu Nomor 1 Tahun 2020 berlaku sejak maret dan menjadi undang-undang setelah disahkan oleh DPR pada bulan Mei 2020. Selain kedua regulasi tersebut diatas juga banyak regulasi lain dalam restrukturisasi.

Adanya pandemi Covid-19 menjadikan pemerintah kembali menyuarakan dan membuat kebijakan mengenai restrukturisasi untuk memulihkan ekonomi nasional. Beberapa cara digunakan untuk merestrukturisasi seperti, hair cut, debt recheduling, debt to asset swap dan debt to equity swap. Juga ada upaya-upaya resrukturisasi yang lain dari pihak perbankan.

Regulasi yang telah dikeluarkan oleh pemerintah dapat dipastikan bisa memulihkan keadaan ekonomi di era pandemi Covid-19. Memulihkan ekonomi di bagian dasar akan berefek pada perbaikan ekonomi nasional. Beberapa regulasi di atas saling melengkapi dan membantu aparat penegak hukum dan instansi yang berhubungan menjadi lebih mudah dalam bekerja dan dapat dengan segera menstabilkan kondisi ekonomi Indonesia.

\subsection{Force Majeure Nisbi Dalam Pandemi COVID-19}

Dalam hukum perjanjian Indonesia dikatakan bahwa tiap orang leluasa untuk melangsungkan perjanjian dengan pihak yang diinginkan. ${ }^{35}$ Selanjutnya, dalam suatu perjanjian dikenal sebuah istilah yaitu force majeure. Suatu keadaan yang tidak terlaksana dalam kontrak perjanjian disebabkan oleh hal-hal tak terduga dan berada di luar batas kemampuan manusia disebut force majeure. Dalam Kitab Undang-Undang Hukum Perdata kondisi kahar di norma Pasal 1244 dan $1245 .{ }^{36}$

Berdasarkan Pasal 1244 dan 1245 KUH Perdata, kondisi kahar harus memenuhi empat syarat dari seorang pelaku yang diiringi dengan pembuktian, yakni: 1) tak ada unsur kesengajaan, 2) pihak yang terhalang untuk memenuhi kewajibannya haruslah beritikad baik, 3) penyebab yang membuat pihak tidak dapat melaksanakan kewajiban adalah suatu hal yang tak terduga, dan 4) suatu hal yang menjadi penyebab tidak

\footnotetext{
35 Anand, G. (2011). Prinsip Kebebasan Berkontrak dalam penyusunan kontrak. Yuridika, 26(26). Bidari, A. S., Simangunsong, F., \& Siska, K. (2020). SEKTOR PERBANKAN di COVID-19. Jurnal Pro Hukum, 9(1), p. 91

${ }^{36}$ Soemadipradja, R. S. S., Op. Cit., p. $72-73$
} 
dapat disalahkan kepadanya. ${ }^{37}$ Selain itu force majeure juga memiliki beberapa unsur dari segi peristiwa yaitu peristiwa yang terjadi disebabkan oleh keadaan alam, peristiwa di luar perkirakan dan peristiwa yang membuktikan terdapat ketidakmampuan untuk melakukan kewajiban dalam waktu tertentu. ${ }^{38}$ Salah satu hal yang menjadi akibat force majeure adalah nakoming atau pembebasan kewajiban bagi debitur untuk pemenuhan prestasi. Pembebasan kewajiban yang bersifat penundaan hingga situasi membaik disebut force majeure nisbi atau relatif. Dalam hal ini, jika halangan yang dihadapi debitur untuk memenuhi kewajiban telah usai atau keadaan telah kembali normal, maka debitur diwajibkan untuk kembali memenuhi prestasinya dan penundaan kewajiban menjadi gugur. ${ }^{39}$

Berlandaskan pada asas itikad baik, manakala para pihak dalam perjanjian komersial mengalami keadaan force majeure yang bersifat relatif, kiranya relevan mempertimbangkan upaya restrukturisasi perjanjian sebagaimana yang kerap diterapkan pada kredit perbankan yang bermasalah. Salah satu bentuk restrukturisasi misalnya dengan melakukan re-scheduling terkait pemenuhan prestasi baik berkaitan dengan bunga, angsuran maupun jangka waktunya diperpanjang, sehingga debitur bisa kembali melakukan pemenuhan prestasinya setelah kondisi keadaan memaksa yang tidak terduga berakhir. ${ }^{40}$ Tidak mudah mengemukakan bahwa suatu keadaan dapat dikategorikan sebagai force majeure, melainkan sangat perlu untuk dibuktikan dengan pengamatan yang seksama. Pembuktian tersebut dapat dilakukan dengan menganalisis apakah bencana tersebut telah memenuhi unsur-unsur yang telah dikemukakan di atas. ${ }^{41}$

Berdasarkan uraian di atas, penulis menganalisis bencana nasional Covid-19 berdasarkan unsur-unsur yang harus terpenuhi sehingga dapat dikategorikan sebagai force majeure. Dengan rincian analisis sebagai berikut: 1. Tidak ada unsur kesengajaan dari pihak dalam hal ini adalah debitur. 2. Covid-19 yang menjadi penyebab debitur tidak dapat menuntaskan kewajibannya merupakan hal yang di luar dugaan dan tidak dapat dipersalahkan karena merupakan gejala non alam. 3. Kondisi memaksa yang terjadi pada masa pandemi Covid-19 tidak memiliki dampak mutlak untuk melaksanakan suatu perjanjian. 4. Terdapat dua keadaan yang terjadi yakni: pertama, keadaan memaksa memang benar adanya dan debitur tetap melaksanakan walau dengan pengorbanan yang lebih besar dari biasanya. Kedua, dalam keadaan lain keadaan memaksa ada namun menyebabkan debitur tidak dapat melaksanakan kewajiban sementara dan setelah keadaan memaksa tersebut hilang debitur bisa kembali memenuhi kewajiban prestasinya. 5. Pembebasan terhadap biaya, rugi dan bunga tetap diperoleh oleh debitur yang dihadapkan pada situasi force majeure namun tidak membatalkan suatu perjanjian. Dan 6. Pemerintah telah menyepakati bahwa Covid-19 merupakan

\footnotetext{
37 Kaya, P. B. T. A. \&, \& Dharmawan, N. K. S., Op. Cit., p. 895

38 Isradjuningtias, A. C. (2020). Force Majeure (Overmacht) Dalam Hukum Kontrak (Perjanjian) Indonesia. Veritas et Justitia, 1(1), p. 136-158

39 Soemadipradja, R. S. S., Op. Cit., p. 12

40 Kaya, P. B. T. A. \&, \& Dharmawan, N. K. S., Op. Cit., p. 899

${ }^{41}$ Isradjuningtias, A. C., Op. Cit., p. 136
} 
bencana nasional seiring dikeluarkannya Peraturan Presiden Nomor 12 tahun 2020.

Berdasarkan analisis yang telah dipaparkan, maka dapat ditarik suatu inti yang sebenarnya pandemi Covid-19 adalah force majeure bersifat relatif, yaitu kondisi kahar tidak bersifat absolut sehingga debitor bisa kembali melaksanakan kewajiban untuk pemenuhan prestasi ketika keadaan yang menghalanginya telah hilang. Selain itu, argumentasi ini juga diperkuat dengan adanya Peraturan Presiden Nomor 12 Tahun 2020.

\subsection{Kebijakan Restrukturisasi Utang Dalam Perpu Nomor 1 Tahun 2020 Bagi UMKM Di Era Pandemi Covid-19}

Untuk mengatasi perekonomian pada masa pandemi Covid-19, Indonesia membutuhkan peraturan perundang-undangan sebagai dasar untuk bertindak. ${ }^{42}$ Pemerintah mengeluarkan UU Nomor 2 Tahun 2020setelah disahkan oleh Dewan Perwakilan Rakyat (DPR). ${ }^{43}$ Berdasarkan pada regulasi tersebut, maka penulis akan mendasarkan analisis dengan mengkaji Perpu Nomor 1 tahun 2020. Dalam stimulus ekonomi didedikasikan untuk UMKM yaitu penggratisan PPh 21 bagi karyawan sektor industri pengolahan penghasil maksimal Rp 200 juta, untuk industri kecil dan menengah pada 19 sektor terdapat pembebasan PPN impor wajib pajak selanjutnya impor tujuan ekspor, dan bagi industri kecil menengah sektor tertentu terdapat pengurangan tarif $\mathrm{PPh}$ sebesar $25 \%$ untuk wajib pajak selanjutnya impor tujuan ekspor. ${ }^{44}$

OJK, BI dan LPM menyambut baik Perpu Nomor 1 Tahun 2020 dan siap membantu masyarakat khususnya yang memiliki UMKM terdampak Covid-19 untuk mempermudah pengajuan restrukturisasi. Pada Senin, 30 Maret 2020, beberapa bank umum memberikan restrukturisasi bagi debitur yang terkena dampak Covid-19 pada nomor: 04A-SPI (bank umum) di antaranya: "Bank Mandiri, BRI, BNI, Panin Bank, Permata Bank, Bank BTPN, DBS, Bank Index, dan Bank Ganesha. Kemudian, ada juga beberapa BPD dan bank umum syariah pada Nomor: 04B-SPI, di antaranya: Bank BJB, Bank BPD Bali, bank NTT, Bank Mandiri Syariah, BNI Syariah, Bank Syariah Bukopin, dan Bank NTB Syariah. Selain itu ada dua perusahaan pembiyaan pada nomor: 04CSPI yaitu Asosiasi Perusahaan Pembiayaan Indonesia (APPI) dan FIFGROUP". ${ }^{5}$

Pemberian restrukturisasi ini diutamakan untuk usaha kecil terutama UMKM, ojek online, pekerja harian dan lain-lain yang terdampak Covid-19 dengan nilai pinjaman

42 Firdaus Anna, F. R. E. (2020). PERLINDUNGAN KEBIJAKAN DISKRESI DALAM PENANGANAN COVID-19 MENURUT UNDANG-UNDANG NO. 2 TAHUN 2020. PAKUAN LAW REVIEW, 6(2), 23-41. https://journal.unpak.ac.id/index.php/palar/article/view/2128, p. 23

${ }^{43}$ Juliani, H., Op. Cit., p. 329

${ }^{44}$ Firdaus Anna, F. R. E., Op. Cit., p. 329

45 OJK. (2020a). Daftar Bank dan Umum/Bank Umum Syariah/BPD/BPR/Perusahaan Pembiayaan yang Memberikan Restrukturasi kepada Nasahabhnya yang Terkena Dampak Covid-19. OJK. https://www.ojk.go.id/id/berita-dan-kegiatan/infoterkini/pages/pengumuman-Restrukturasi-atau-keringanan-bagi-debitur-perbankan-danperusahaan-pembiayaan-yang-terkena-dampak-covid-19.aspx 
di bawah Rp 10. Para pelaku usaha yang telah disebut di atas mengalami kesusahan membayar cicilan kredit atau utang sejak adanya Covid-19. Kemudian, debitor tak terdapatdidaftar hitam nasional, kolektabilitas performing loan, prospek usaha bagus, mau kerja sama. Disamping itu, bank tetap mempunyai penilaian tersendiri terhadap debitor bisa menerima restrukturisasi hutang. Pemberian restrukturisasi ini dilakukan selektif karena bank juga mengalami pengurangan pemasukan akibat terkena dampak Covid-19, sementara walaupun pemasukan berkurang perusahaan bank harus tetap membayar bunga pada penabung / investor dan mengeluarkan biaya operasional seperti menggaji karyawan, listrik, air dan lain-lain. Apabila harus menghapus semua utang yang ada, bank bisa terancam tutup dan akan berimbas membahayakan ekonomi Indonesia. Per 2 Juni 2020, sebanyak 99 Bank Umum Konvensional / Syariah dengan total debitur 5,94 juta telah direstrukturasi dengan nilai Rp.609,07 T dan 4,96 juta adalah debitur UMKM dengan nilai restrukturasi Rp.282,64T. Kemudian, per 5 Juni 2020, Industri Keuangan Non Bank yaitu 183 Perusahaan Pembiayaan dengan 2,82 kontrak pembiayaan dengan nilai Rp.84,38T telah direstrukturasi. ${ }^{46}$

Rescheduling adalah model restrukturisasi yang digunakan untuk mencapaipersetujuan perdamaian. ${ }^{47}$ Metode restrukturisasi utang yang memudahkan debitur untuk menyelesaikan kewajiban, menyampaikan tempat khusunya bagi debitur UMKM guna memberikan dana dahulu. Kemudahan ini dimohonkan berefek selaksa merefleksikan pada peningkatan keuangan yang bisa diamati dari signifikansi terhadap kemajuan keuangan saat periode sebelum serta sesudah restrukturisasi hutang dilaksanakan. ${ }^{48}$ UMKM yang terimbas wabah Covid-19 yang tak berdaya melaksanakan keharusan pelunasan hutang diharapkan dapat dibantu dengan adanya program restrukturisasi. Sampai saat ini, Sektor keuangan tetap dalam kondisi terjaga. OJK, BI, dan LPS akan mengoptimalkan berbagai kebijakan termasuk restrukturisasi.

Perpu Nomor 1 Tahun 2020 menuai banyak kritik dari masyarakat indonesia terkait dengan pelaksanaan, urgensitas, dasar konstitusional dan yang terburuk adalah substansi dari Perpu Nomor 1 Tahun 2020 dianggap membuka peluang korupsi disebabkan tak ada proses secara hukum dengan mengajukan pengujian ke Mahkamah Konstitusi. ${ }^{49}$ Kebijakan strategis komprehensif melahirkan kesatuan tindakan secara nasional dalam menangani Covid-19 dan mengantisipasi

46 Update, O. (2020). Kebijakan Stimulus OJK Menjaga Fundamental Sektor Riil Dan Perkembangan Pelaksanaan Restrukturasi Kredit/Pembiayaan. OJK Update. https://www.ojk.go.id/id/berita-dan-kegiatan/Dokuments/Pages/Informasi-Covid-19, www.ojk.go.id

47 Amboro, F. Y. P. (2020). RESTRUKTURISASI UTANG TERHADAP PERUSAHAAN GO PUBLIC DALAM KEPAILITAN DAN PKPU. Masalah-Masalah Hukum, 49(1), 103-111. https://doi.org/10.14710/mmh.49.1.2020.103-111, p. 111

${ }^{48}$ Rudiana, D. A. \&, \& Venusita, L. (n.d.). Dampak Restrukturasi Utang Pada Kinerja Keuangan Perusahaan. Jurnal Akuntansi. https://jurnalmahasiswa.unesa.ac.id/index.php/jurnalakuntansi/article/viewFile/27004/24716, p. 4

${ }^{49}$ Iswanto, Iswanto \& Surisman, S. (2020). PERLUKAH PERPU NO. 1 TAHUN 2020 TENTANG KEBIJAKAN KEUANGAN NEGARA CORONA VIRUS DISEASE 2019 (COVID-19). Legal Standing : Jurnal Ilmu Hukum, 4(1), 280-288. http://journal.umpo.ac.id/index.php/LS/article/view/2770, p. 280-281 
dampaknya. ${ }^{50}$ Dengan dikeluarkannya Perpu Nomor 1 Tahun 2020 merupakan diskresi konstitusional. Setiap pejabat pemerintah memiliki Freies Ermessen atau diskresi yang digunakan untuk mengambil kebijakan dalam mengatasi persoalan yang mendesak dan membutuhkan penanganan cepat. Setiap pejabat pemerintah yang melakukan tindakan atas nama jabatan akan dilindungi karena kebijakan tersebut memiliki payung hukum. Pelaksanaan diskresi di tengah keadaan genting penting sekali untuk diawasi agar tidak terjadi penyelewengan. Bentuk pengawasan tersebut adalah dengan cara internal berlandaskan persyaratan yang ada di norma UndangUndang Nomor 30 tahun 2014 dan asas-asas umum kepemerintahan yang baik. Selanjutnya, secara eksternal, masyarakat diharap ikut andil untuk melakukan pengawasan dan penyeimbang terhadap jalannya penyelenggaraan negara. ${ }^{51}$

Dari analisis yang telah dipaparkan di atas, dapat disimpulkan bahwa tingginya angka debitur yang mengajukan restrukturisasi menandakan bahwa debitur menyambut baik dan sangat membutuhkan adanya resrukturisasi. Restrukturasi membantu seluruh pihak terutama pelaku usaha yang terdampak Covid-19, pihak perbankan, pihak keuangan, dan lembaga lain yang dipermudah sehingga memiliki harapan untuk dapat bangkit serta memperbaiki perekonomiannya. Menurut peneliti kebijakan restrukturisasi yang digemakan oleh pemerintah merupakan langkah yang sangat tepat untuk diambil pada era pandemi Covid-19. Dengan adanya restrukturisasi utang, pelaku usaha khususnya UMKM dapat lebih lega menghadapi perekonomian individu yang terdampak Covid-19 sehingga pelahan pelaku usaha tersebut dapat bangkit dan memperbaiki perekonomiannya. Selain itu, dengan mengoptimalkan restrukturisasi dan kebijakan lain, juga dapat lebih cepat memulihkan ekonomi nasional.

\section{Kesimpulan}

Dasar pengaturan restrukturisasi di era pandemi Covid-19 adalah UU PKPU, Perpu Nomor 1 Tahun 2020 dan UU Nomor 2 Tahun 2020. UU PKPU awal dibentuk bertujuan untuk memulihkan krisis ekonomi Indonesia pada tahun 1998. Di masa pandemi Covid-19, pemerintah kembali menggemakan restrukturisasi dengan mengeluarkan regulasi untuk membantu pelaku usaha bangkit dari krisis sehingga nantinya juga akan berdampak pada eknomi nasional yang membaik. Masa pandemi Covid-19 merupakan force majeure nisbi atau relatif setelah ditetapkan sebagai bencana nasional. Disebut relatif karena Covid-19 tidak memiliki dampak mutlak yang akan menyebabkan berakhirnya sebuah perjanjian. Keadaan memaksa hanya bersifat relatif yaitu debitur tidak dapat melaksanakan kewajiban hanya sementara dan setelah keadaan memaksa hilang maka debitur wajib untuk memenuhi prestasinya. Langkah pemerintah untuk bertahan di masa pandemi Covid-19 dari segi ekonomi adalah dengan restrukturisasi yang diiringi dengan dikeluarkannya Perpu Nomor 1 Tahun 2020 yang kemudian disahkan oleh DPR menjadi UndangUndang Nomor 2 Tahun 2020. Langkah pemerintah yang melambangkan kebijakan. Diskresi memang berbahaya, untuk itu perlu untuk diawasi dari sisi internal maupun eksternal. Adanya Perpu Nomor 1 Tahun 2020, disambut

\footnotetext{
${ }^{50}$ Julaiddin, Julaiddin \& Sari, H. P. (2020). Kebijakan Hukum Di Tengah Penanganan Wabah Corona Virus Disease (Covid-19). UNES Law Review, 4(4), 358-371. https://reviewunes.com/index.php/law/article/view/123, p. 369

51 Ibid., p. 369
} 
baik oleh masyarakat ditandai dengan tingginya angka debitur yang mengajukan restrukturisasi baik perbankan maupun non perbankan. Program restrukturisasi ini dapat membantu pelaku UMKM yang nantinya akan berefek pada ekonomi nasional yang membaik.

\section{Daftar Pustaka}

\section{Buku}

Ibrahim, J. (2008). Teori Metodologi Penelitian Hukum Normatif. Bayumedia Publishing.

Marzuki, P. M. (2016). Penelitian Hukum. Kencana Prenadamedia Group.

Soemadipradja, R. S. S. (2010). Penjelasan Hukum tentang Keadaan Memaksa. Nasional Legal Reform Program.

Suyatno, R. A. (2012). Pemanfaatan Penundaan Kewajiban Pembayaran Utang: Sebagai Upaya Mencegah Kepailitan. Kencana Prenada Media Group.

\section{Jurnal}

Amboro, F. Y. P. (2020). RESTRUKTURISASI UTANG TERHADAP PERUSAHAAN GO PUBLIC DALAM KEPAILITAN DAN PKPU. Masalah-Masalah Hukum, 49(1), 103-111. https://doi.org/10.14710/mmh.49.1.2020.103-111

Anand, G. (2011). Prinsip Kebebasan Berkontrak dalam penyusunan kontrak. Yuridika, 26(26).

Bidari, A. S., Simangunsong, F., \& Siska, K. (2020). SEKTOR PERBANKAN di COVID19. Jurnal Pro Hukum, 9(1).

Firdaus Anna, F. R. E. (2020). PERLINDUNGAN KEBIJAKAN DISKRESI DALAM PENANGANAN COVID-19 MENURUT UNDANG-UNDANG NO. 2 TAHUN 2020. PAKUAN LAW REVIEW, 6(2), 23-41. https://journal.unpak.ac.id/index.php/palar/article/view/2128

Hanoatubun, S. (2020). Dampak Covid-19 terhadap Prekonomian Indonesia. EduPsyCouns: Journal of Education, Psychology and Counseling, 2(1), 146-153. https:/ / ummaspul.e-journal.id/Edupsycouns/article/view/423

Hariyadi, H. (2020). Restrukturasi Utang Sebagai Upaya Pencegahan Kepailitan Pada Perseroan Terbatas. SIGn Jurnal Hukum, 1(2).

Isradjuningtias, A. C. (2020). Force Majeure (Overmacht) Dalam Hukum Kontrak (Perjanjian) Indonesia. Veritas et Justitia, 1(1).

Iswanto, Iswanto \& Surisman, S. (2020). PERLUKAH PERPU NO. 1 TAHUN 2020 TENTANG KEBIJAKAN KEUANGAN NEGARA CORONA VIRUS DISEASE 2019 (COVID-19). Legal Standing : Jurnal Ilmu Hukum, 4(1), 280-288. http://journal.umpo.ac.id/index.php/LS/article/view/2770

Julaiddin, Julaiddin \& Sari, H. P. (2020). Kebijakan Hukum Di Tengah Penanganan Wabah Corona Virus Disease (Covid-19). UNES Law Review, 4(4), 358-371. https://review-unes.com/index.php/law/article/view/123

Juliani, H. (2020). Analisis Yuridis Kebijakan Keuangan Negara dalam Penanganan Pandemi Covid-19 Melalui Peraturan Pemerintah Pengganti Undang-Undang 
Nomor 1 Tahun 2020. Administrative Law \& Governance Journal, 3(2), 329-348. https://ejournal2.undip.ac.id/index.php/alj/article/view/8043

Kaya, P. B. T. A. \&, \& Dharmawan, N. K. S. (2020). Kajian Force Majeure Terkait Pemenuhan Prestasi Perjanjian Komersial Pasca Penetapan Covid-19 Sebagai Bencana Nasional. Kertha Semaya : Journal Ilmu Hukum; Vol 8 No 6 (2020), 8(6), 891-901. https://ojs.unud.ac.id/index.php/kerthasemaya/article/view/60631

Marlinah, L. (2020). Peluang dan Tantangan UMKM Dalam Upaya Memperkuat Perekonomian Nasional Tahun 2020 Ditengah Pandemi Covid 19. Jurnal Ekonomi, 22(2).

Pramudita, S. A., Kartikasari \& Cahyadini, A. (2020). Kedudukan Hukum Menkominfo Dalam Pelaksanaan Perdamaian Menurut Undang-Undang Nomor 37 Tahun 2004 Tentang Kepailitan dan Penundaan Kewajiban Pembayaran Utang. Jurnal Ilmu Hukum Legal Standing, 4(1).

Respatia, W \& Fidiana, F. (2010). Kebijakan Restrukturasi Utang Melalui Debt to Equity Swap. Ekuitas, 14(1).

Rudiana, D. A. \&, \& Venusita, L. (n.d.). Dampak Restrukturasi Utang Pada Kinerja Keuangan Perusahaan. Jurnal Akuntansi. https://jurnalmahasiswa.unesa.ac.id/index.php/jurnalakuntansi/article/viewFile/27004/24716

Sunarmi, R. Harianto, D. \& Azwar, T. K. D. (2016). Konsep Utang dalam Hukum Kepailitan Dikaitkan dengan Pembuktian Sederhana (Studi Putusan No: 04/PDT.SUS.PAILIT/2015/PN.NIAGA.JKT/PST). USU Law Journal, 4(4).

Yuliana, Y. (2020). Corona Virus Disease (Covid-19): Sebuah Tinjauan Literatur. Wellnes and Healthy Magazine, 2(1).

\section{Peraturan Perundang-Undangan / Putusan Pengadilan}

Indonesia, M. K. R. (n.d.). Putusan Mahkamah Konstitusi Republik Indonesia Nomor 138/PUU-VII/2009.

Undang-Undang Nomor 37 Tahun 2004 Tentang Kepailitan Dan Penundaan Kewajiban Pembayaran Utang, (2004).

Peraturan Pemerintah Pengganti Undang-Undang Nomor 1 Tahun 2020 Tentang Kebijakan Keuangan Negara dan Stabilitas Sistem Keuangan untuk Penanganan Pandemi Corona Virus Disease 2019 (COVID-19) dan/atau dalam Rangka Menghadapi Ancaman yang Membahayakan Perekonomian Nasional dan/atau Stabilitas Sistem Keuangan.

Indonesia, M. K. R. (n.d.). Putusan Mahkamah Konstitusi Republik Indonesia Nomor 138/PUU-VII/2009.

Undang-Undang Nomor 37 Tahun 2004 Tentang Kepailitan Dan Penundaan Kewajiban Pembayaran Utang, (2004).

Peraturan Pemerintah Pengganti Undang-Undang Nomor 1 Tahun 2020 Tentang Kebijakan Keuangan Negara Dan Stabilitas Sistem Keuangan Untuk Penanganan 
Pandemi Covid-19 Dan/Atau Dalam Rangka Menghadapi Ancaman Yang Membahayakan Perekonomian Nasional Dn/Atau Sta, (2020).

Undang-Undang Dasar Negara Republik Indonesia Tahun 1945, (1945).

\section{Internet/Website}

Indonesia, C. (2020). Update Corona 3 Agustus : 113.134 Positif, 70.273 Sembuh. CNN Indonesia. $\quad$ https://m.cnnindonesia.com/nasional/20200803144603-20531637/update-corona-3-agustus-113134-positif-70237-sembuh/

Indonesia, G. (2020). Peraturan Perbankan. GB Indonesia. https://www.bi.go.id/id/peraturan/perbankan/Documents/1cd6b7873ef54732 b2981218c54aaaa30pbi7205c1.pdf

OJK. (2020a). Daftar Bank dan Umum/Bank Umum Syariah/BPD/BPR/Perusahaan Pembiayaan yang Memberikan Restrukturasi kepada Nasahabhnya yang Terkena Dampak Covid-19. OJK. https://www.ojk.go.id/id/berita-dankegiatan/info-terkini/pages/pengumuman-Restrukturasi-atau-keringanan-bagidebitur-perbankan-dan-perusahaan-pembiayaan-yang-terkena-dampak-covid19.aspx

OJK. (2020b). Siaran Pers: OJK Mendukung dan Menindaklanjuti PERPU 1 Tahun 2020. Siaran Pers. https://www.ojk.go.id/id/berita-dan-kegiatan/siaranpers/Pages/Siaran-Pers-OJK-Mendukung-dan-Menindaklanjuti-PERPU-1Tahun-2020.aspx

Rizki, M. J. (2020). Praktisi Hukum dan Bankir Harapan Restrukturasi Utang Jadi "Obat" Covid-19. Www.hukumonline.com. https://www.hukumonline.com/berita/baca/lt5f06e66c6cebc/praktisi-hukumdan-bankir-harapkan-restrukturisasi-utang-jadi-obat-covid-19/

Sidik, S. (2020). OJK: Restrukturasi Nasabah Leasing Sudah Tembus Rp. 134 T. Cnbcindonesia. https://www.cnbcindonesia.com/market/20200708120817-17171108/ojk-restrukturasi-nasabah-leasing-sudah-tembus-rp-134-t

Update, O. (2020). Kebijakan Stimulus OJK Menjaga Fundamental Sektor Riil Dan Perkembangan Pelaksanaan Restrukturasi Kredit/Pembiayaan. OJK Update. https://www.ojk.go.id/id/berita-dan-kegiatan/Dokuments/Pages/InformasiCovid-19, www.ojk.go.id 